\title{
UPAYA MENINGKATKAN HASIL BELAJAR SEPAKBOLA DENGAN PENERAPAN VARIASI MENGAJAR MENGGIRING BOLA PADA SISWA/I KELAS VIII SMP KARTIKA 1 - 2 MEDAN TAHUN AJARAN 2014/2015.
}

\author{
Mahmuddin, Aulia Rahman \\ Fakultas Ilmu Keolahragaan, Universitas Negeri Medan, Medan, Indonesia \\ Correspondence: Fakultas Ilmu Keolahragaan, Universitas Negeri Medan, Medan, \\ Indonesia. E-mail:
}

\begin{abstract}
ABSTRAK
Penelitian ini dilaksanakan di SMP Kartika 1 - 2 Medan Tahun Ajaran 2014/2015. Penelitian ini dilakukan dalam dua siklus, dimana setiap siklus berisikan tindakan berupa penerapan variasi belajar yang disesuaikan dengan materi pelajaran. Populasi dalam penelitian ini adalah kelas VIII SMP SMP Kartika 1 - 2 Medan Tahun Ajaran 2014/2015 dengan subjek penelitian sebanyak 27 orang. Metode penelitian ini adalah Penelitian Tindakan kelas (Classroom Action Research). Untuk memperoleh data dalam penelitian ini maka dilakukan tes hasil belajar I dan tes hasil belajar II yang berbentuk aplikasi teknik menggiring bola dalam permainan sepak bola sebanyak dua kali pertemuan. Setelah data terkumpul dan dilakukan analisis pada penilaian proses maka diperoleh hasil analisisnya : Pada siklus I setelah tes hasil belajar I dapat dilihat bahwa dari 27 orang siswa yang menjadi subjek dalam penelitian ini, ternyata hanya 10 orang siswa (40,74\%) yang sudah memiliki ketuntasan belajar, sedangkan selebihnya yaitu 17 orang siswa $(59,26 \%)$ belum memiliki ketuntasan belajar. Nilai rata - rata yang diperoleh hanya mencapai 75,00. Pada siklus II dapat dilihat bahwa ternyata dari 27 orang siswa, terdapat 25 orang siswa yang tuntas (92,59\%) yang sudah memiliki ketuntasan belajar, sedangkan selebihnya yaitu 2 orang siswa (7,41\%) belum memiliki ketuntasan belajar. Nilai rata - rata yang diperoleh hanya mencapai 83,95. Penilaian hasil teknik menggiring bola yang dilakukan dengan menggiring bola dengan mengelilingi cone. Pada sirklus I rata - rata kelas VIII mampu menggiring bola mengelilingi cone selama 23,86 detik dimana termasuk dalam kategori cukup. Pada sirklus II rata - rata kelas VIII mampu menggiring bola mengelilingi cone selama 21,38 detik dimana termasuk dalam kategori baik. Berdasarkan hal itu maka dapat ditarik kesimpulan bahwa penerapan variasi belajar dapat meningkatkan hasil belajar menggiring bola dalam permainan sepak bola pada siswa kelas VIII SMP Kartika 1 - 2 Medan Tahun Ajaran 2014/2015.
\end{abstract}

\section{Kata Kunci: Hasil Belajar Sepakbola Dengan Penerapan Variasi Mengajar}

\section{Pendahuluan}

Sekolah merupakan lembaga pendidikan yang mempunyai tugas untuk menghantarkan peserta didik mengembangkan segala potensi yang dimilikinya. Sekolah juga dipercaya sebagai satu-satunya cara agar manusia pada zaman sekarang dapat hidup lebih baik dimasa yang akan datang. Keberhasilan pendidikan di sekolah sangat tergantung 
pada proses belajar mengajar di kelas. Kegiatan belajar mengajar bertujuan untuk membawa peserta didik pada perubahan tingkah laku yang diinginkan.

Pengertian ini kelihatan cukup simpel dan sederhana, akan tetapi bila pengertian ini ditelaah lebih dalam, maka akan terlihat lebih rumit dan begitu kompleksnya proses yang dituntut dalam mengelola pelajaran itu sendiri. Hal ini bisa dipahami karena membawa peserta didik ke arah perubahan yang diinginkan. Dalam proses pembelajaran di sekolah terdapat banyak unsur yang saling berkaitan dan menentukan dalam proses belajar mengajar. Unsur-unsur tersebut adalah pendidik (guru), peserta didik (siswa), kurikulum pengajaran, tes dan lingkungan. Siswa sebagai subjek dalam proses pembelajaran tersebut juga sangat berperan dalam keberhasilan belajar mengajar.

Pendidikan jasmani adalah suatu proses pendidikan yang dilakukan secara sadar dan sistematis melalui berbagai aktivitas jasmani dalam rangka memperoleh kemampuan dan keterampilan jasmani, pertumbuhan fisik, kecerdasan dan pertumbuhan watak. Sebagai sub sistem dari pendidikan nasional, kegiatan jasmani di sekolah wajib diikuti oleh semua siswa.

Pembelajaran Pendidikan Jasmani di sekolah masih cenderung dilaksanakan dengan menggunakan pendekatan teknis dalam mengajarkan suatu cabang olahraga. Artinya, menitik beratkan pada penguasaan teknik dasar kecabangan dan kurang mementingkan kemampuan pemahaman siswa terhadap hakekat permainan itu sendiri. Penerapan pendekatan teknis akan menyulitkan siswa dalam memahami makna permainan dalam suatu cabang olahraga, dampaknya siswa tidak tertarik pada proses pembelajaran. Suasana yang kurang menyenangkan dan menggembirakan tersebut akan membuat siswa kurang termotivasi dalam mengikuti pelajaran pendidikan jasmani di sekolah atau di luar sekolah.

Salah satu cabang olahraga yang populer yang terdapat di kurikulum pendidikan baik ditingkat SD, SMP, SMA maupun SMK yaitu Permainan sepak bola. Sepak bola adalah merupakan permainan yang dimainkan oleh dua regu yang masing-masing regu terdiri dari 11 orang pemain, bermain untuk memasukkan sebuah bola bundar ke gawang lawan (mencetak gol).

Oleh karena itu, untuk dapat melakukan permainan sepak bola, pemain atau siswa harus menguasai teknik-teknik dasar sepak bola yang baik. Teknik dasar bermain sepak bola adalah cara pengolahan bola maupun pengolahan gerakan tubuh dalam bermain sepak bola. Untuk dapat bermain sepak bola dengan baik, pemain atau siswa harus menguasai teknik dasar sepak bola dengan baik. Teknik-teknik dasar dalam permainan sepak bola terdiri dari beberapa macam yaitu, stop ball (menghentikan bola), shooting (menendang bola ke gawang), passing (mengumpan), heading (menyundul bola), dan dribbling (menggiring bola). Khususnya dalam teknik dribbling (menggiring bola), pemain harus menguasai teknik yang telah dipelajari dengan baik, karena teknik menggiring bola (dribbling) adalah salah satu teknik yang sangat berpengaruh terhadap permainan para pemain sepak bola.

\section{Hakikat Permainan Sepak Bola}

Sepak bola merupakan permainan beregu, masing-masing regu terdiri atas sebelas pemain dan salah satunya penjaga gawang. Permainan ini hampir seluruhnya dimainkan 
dengan menggunakan tungkai, kadangkala menggunakan kepala dan dada. Khusus untuk penjaga gawang diperbolehkan untuk menggunakan tangan dan lengannya didaerah kotak enam belas meter/ area penalti. Permainan sepak bola dapat dilakukan dilapangan terbuka dan lapangan tertutup yang dimainkan oleh semua kalangan usia. Menurut Mukholid (2007:2) bahwa “Dalam permainan sepak bola terdapat beberapa teknik dasar yang antara satu dengan yang lain sangat erat kaitanya dalam permainan sepak bola". Adapun teknik dasar sepak bola diantaranya:

a) Teknik menendang bola (Shooting), dapat dilakukan dengan menggunakan: Kaki bagian dalam, kaki bagian luar, punggung kaki, punggung kaki bagian dalam.

b) Teknik mengoper bola (Passing), dapat dilakukan dengan menggunakan: Kaki bagian dalam, kaki bagian luar, punggung kaki, dada, paha dan kepala.

c) Teknik menggiring bola (Drible), dapat dilakukan dengan menggunakan: kaki bagian dalam, kaki bagian luar, punggung kaki.

d) Teknik mengontrol bola (Dropping).

e) Teknik merebut bola (Tackling)

f) Teknik menyundul bola (Heading).

\section{Hakikat Menggiring Bola.}

Pada dasarnya permainan sepak bola merupakan suatu usaha untuk menguasai bola dan untuk merebutnya kembali bila sedang dikuasai oleh lawan. Oleh karena itu, untuk dapat melakukan permainan sepak bola harus menguasai teknik-teknik dasar sepak bola yang baik. Untuk dapat menghasilkan permainan sepak bola yang optimal, maka seorang pemain harus dapat menguasai teknik-teknik dalam permainan. Teknik dasar bermain sepak bola adalah merupakan kemampuan untuk melakukan gerakan-gerakan atau mengerjakan sesuatu yang terlepas sama sekali dari permainan sepak bola.

Sepak bola modern dilakukan dengan keterampilan lari dan operan bola dengan gerakan-gerakan yang sederhana disertai dengan kecepatan dan ketepatan. Aktivitas dalam permainan sepak bola tersebut dikenal dengan nama dribbling (menggiring bola). Seiring dengan itu, Danny Mielke (2007:1) mengemukan bahwa "dribbling (menggiring bola) adalah keterampilan dasar dalam sepak bola, karena semua pemain harus mampu menguasai bola pada saat sedang bergerak, berdiri atau bersiap melakukan operan atau tembakan". Penggunaan dribbling (menggiring bola) dalam suatu permainan tergantung pada bidang permainan, kedekatan dengan lawan atau teman satu tim, kondisi lapangan, dan tentu saja keterampilan serta percaya diri.

Menurut Sucipto, dkk (2000:9), Pelaksanaan pada saat melakukan dribbling (menggiring bola) dengan menggunakan kaki bagian dalam adalah sebagai berikut :

$\checkmark$ Posisi kaki dribbling (menggiring bola) sama dengan posisi menendang bola.

$\checkmark$ Kaki yang digunakan untuk dribbling (menggiring bola) tidak ditarik kebelakang hanya diayunkan ke depan.

$\checkmark$ Diupayakan setiap melangkah, secara teratur bola disentuh/didorong bergulir kedepan.

$\checkmark$ Bola bergulir harus selalu dekat dengan kaki dengan demikian bola tetap dikuasai. 
Pada waktu dribbling bola kedua lutut sedikit ditekuk untuk mempermudah penguasaan bola.

$\checkmark$ Pada saat kaki menyentuh bola, pandangan ke arah bola dan selanjutnya melihat situasi lapangan.

$\checkmark$ Kedua lengan menjaga keseimbangan disamping badan.

$\checkmark$ Untuk lebih jelasnya, dapat dilihat pada gambar dibawah .

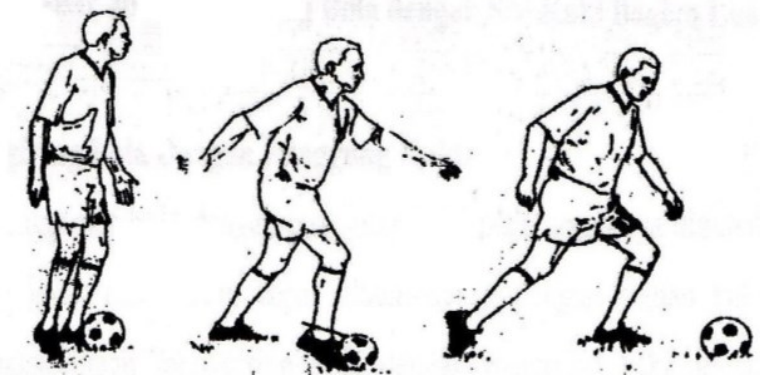

\section{Gambar . Dribbling Bola Dengan Kaki Bagian Dalam}

Penguasaan teknik menggiring bola yang baik memungkinkan seorang pemain mampu menciptakan gol. Oleh karena itu menggiring bola memiliki peranan yang sangat penting dan tidak dapat dikesampingkan. Seiring dengan itu Danny Mielke (2007:1) mengemukakan bahwa "Dribbling adalah keterampilan dasar dalam sepak bola, karena semua pemain harus mampu menguasai bola pada saat sedang bergerak, berdiri, atau bersiap melakukan operan atau tembakan". Penggunaan dribbling (menggiring bola) didalam suatu permainan tergantung pada bidang permainan, kedekatan dengan lawan atau teman satu tim, kondisi lapangan, dan tentu saja keterampilan serta percaya diri.

Nusri (2003:21) menambahkan bahwa "Prinsip menggiring bola yang baik yaitu harus memperhatikan langkah kaki, kecepatan dan dorongan". Tidak lepas dari hal itu penguasaan teknik menggiring bola yang baik akan memberi nilai lebih bagi seorang pemain, karena dari keterampilan menggiring bola yang dipertunjukkan akan jelas kelihatan seberapa jauh kapasitas seorang pemain tersebut dalam menguasai teknik dasar bermain sepak bola. Teknik dasar, khususnya menggiring bola dapat ditingkatkan melalui latihanlatihan yang sifatnya mampu membina aspek kognitif, afektif, dan psikomotor. Latihan yang baik dan terprogram secara berkelanjutan serta disesuaikan dengan kondisi siswa yang sebenarnya, merupakan faktor yang paling penting guna mencapai tujuan latihan.

\section{Hakikat Pendidikan Jasmani}

Pendidikan jasmani pada hakikatnya adalah proses pendidikan yang memanfaatkan aktifitas fisik untuk menghasilkan perubahan holistic dalam kualitas individu, baik dalam hal fisik, mental, serta emosional. Pendidikan jasmani memperlakukan anak sebagai sebuah kesatuan utuh, makhluk total, daripada hanya menganggapnya sebagai seseorang yang terpisah kualitas fisik dan mentalnya. Rusli Lutan (2000:1) menjekaskan, pendidikan jasmani adalah wahana untuk mendidik anak muda agar kelak mereka mampu membuat 
keputusan terbaik tentang aktifitas jasmani yang di lakukan dan menjalani pola hidup sepanjang hayat.

Nasidah (1992:15) mengutip pendapat Sharman bahwa penjas adalah bagian dari pendidikan (secara umum) yang berlangsung melalui aktifitas fisik yang melibatkan mekanisme gerak tubuh manusia dan menghasilkan pola-pola perilaku pada individu yang bersangkutan.

\section{Hakikat Hasil Belajar}

Hasil belajar memacu pada terjadinya perubahan tingkah laku pada diri siswa yang dapat diamati dan diukur dalam bentuk perubahan pengetahuan, sikap dan keterampilan. Hasil belajar merupakan indikator untuk mengukur tingkat keberhasilan siswa dalam proses belajar mengajar. Indikator keberhasilan sebagai alat ukur untuk mengetahui tingkat keberhasilan siswa dalam melakukan tindakan belajar.

Menurut Slameto (2010:7) "hasil belajar siswa adalah kemampuan yang dicapai siswa setelah proses belajar mengajar". Jadi, tingkat pencapaian hasil belajar siswa diperoleh setelah mengikuti proses hasil belajar. Belajar adalah perubahan tingkah laku yang relatif mantap berkat latihan dan pengalaman. Belajar yang dilakukan oleh manusia merupakan bagian dari hidupnya, berlangsung seumur hidup, kapan saja, dan di mana saja, baik di sekolah, di kelas, di jalanan, dalam waktu yang tidak dapat ditentukan sebelumnya.

Selanjutnya menurut Bloom dalam Suprijono (2010:4) menyatakan bahwa: Hasil belajar mencakup kemampuan kognitif, afektif, dan psikomotor. Domain kognitif adalah knowledge (pengetahuan, ingatan), comprehension (pemahaman, menjelaskan, meringkas, contoh), application (menerapkan), analysis (menguraikan, menentukan hubungan), synthesis (mengorganisasikan, merencanakan, membentuk bangunan baru), dan evaluation (menilai). Domain afektif adalah receiving (sikap penerimaan), responding (memberikan respon), valuing (nilai), organization (organisasi), characterization (karakteristik). Psikomotor juga mencakup keterampilan produktif, teknik, fisik, sosial, manajerial, dan intelektual.

Dalam konteks merancang sistem belajar, konsep belajar ditafsirkan berbeda. Belajar dalam hal ini harus dilakukan dengan sengaja, direncanakan sebelumnya dengan struktur tertentu. Maksudnya, agar proses belajar dan hasil-hasil yang dicapai dapat dikontrol secara cermat. Guru dengan sengaja menciptakan kondisi dan lingkungan yang menyediakan kesempatan belajar kepada para siswa untuk mencapai tujuan tertentu.

Faktor-faktor yang mempengaruhi hasil belajar siswa menurut Slameto (2010:54) antara lain:

1. Faktor intern adalah yang ada dari dalam diri individu yang sedang belajar yang terdiri dari tiga yaitu:

a. Faktor jasmaniah, ini akan mempengaruhi kegiatan belajar siswa. Ada dua yang mempengaruhi proses belajar siswa yaitu kesehatan dan cacat tubuh.

b. Faktor psikologis, ini pada umumnya dipandang lebih esensial yang terdiri dari inteligensi, perhatian, minat, bakat, motif, kematangan dan kelelahan. 
c. Faktor kelelahan, dapat dibedakan menjadi dua macam yaitu kelelahan jasmani dan kelelahan rohani. Dimana kelelahan jasmani membaring tubuh dan kecenderungan untuk membaringkan tubuh., sedangkan kelelahan rohani dilihat dari kelesuan dan kebosanan sehingga minat dan dorongan untuk belajar hilang.

2. Faktor ekstern adalah yang ada di luar individu yang terdiri dari tiga yaitu:

a. Faktor keluarga, dimana keluarga dapat mendukung setiap kegiatan yang dilakukan siswa dalam proses belajar. Siswa akan menerima pengaruh berupa bagaimana cara orangtua mendidik anak, relasi yang baik antar anggota keluarga, suasana di dalam rumah, dan keadaan ekonomi keluarga.

b. Faktor sekolah, dimana sekolah akan mempengaruhi baik tidaknya siswa dalam kegiatan belajarnya yang dilihat dari metode guru dalam mengajar, kurikulum yang digunakan, relasi guru dengan siswa, disiplin sekolah, pelajaran dan waktu sekolah, standar pelajaran, keadaan sekolah dan tugas yang diberikan.

c. Faktor masyarakat, dimana siswa berhubungan secara langsung atau tidak langsung dengan lingkungan tempat tinggalnya. Hal ini yang mempengaruhi kegiatan belajar siswa dalam lingkungan dengan dipengaruhi mass media, teman bermain, dan bentuk kehidupan masyarakat sekitar tempat tinggal.

Menggiring bola dalam permainan sepak bola merupakan salah satu mata pelajaran pokok yang diajarkan di SMA maupun SMK. Taraf penyampaian hasil belajar disebut sebagai hasil belajar yang dalam hal ini khususnya belajar menggiring bola sepak bola.

\section{Hakikat Variasi Mengajar}

Menggunakan variasi diartikan sebagai perbuatan guru dalam proses belajar mengajar yang bertujuan mengatasi kebosanan siswa, sehingga dalam proses belajarnya siswa senantiasa menunjukkan ketekunan, keantusiasan, serta berperan secara aktif. Faktor kebosanan disebabkan oleh adanya penyajian kegiatan belajar yang begitu-begitu saja akan mengakibatkan perhatian, motivasi dan minat siswa terhadap pelajaran, guru dan sekolah. Untuk itu diperlukan adanya keanekaragaman atau yang sering disebut variasi dalam penyaji kegitan belajar.

\section{Manfaat Variasi}

Seperti yang disampaikan dalam hakikat variasi diatas, mengemukakan bahwa pengaruh variasi tindakan dan perubahan guru dalam bidang kegiatan pembelajaran terhadap siswa sangatlah efektif untuk mengacu, mengembangkan atau mengikat perhatian siswa selama pembelajaran berlangsung. Variasi tindakan dan perbuatan guru itu, baik yang disadari maupun yang terjadi secara spontan.

Dengan demikian mempunyai manfaat seperti yang dikemukakan oleh : Simaremare ( 2007 : 23 ) untuk : a) Mengurangi kebosanan siswa dalam mengikuti pembelajaran, b) Meningkatkan motivasi siswa, Mengacu mengembangkan serta mengikat perhatian siswa pada pelajaran yang mereka ikuti, c) Menumbuhkan rasa ingin tahu siswa pada hal-hal baru sedang dipelajari, d) Menumbuhkan perilaku belajar positif pada siswa, e) Meningkatkan parisipasi siswa dalam interaksi kegiatan pembelajaran, f) Memperlancar dan memperjelas komunikasi antara guru dan siswa. 
2. Jenis-Jenis variasi Latihan

Jenis-jenis variasi seperti yang dikemukakan oleh: Mielke (2007:7) menemukan contoh variasi latihan untuk dribbling antara lain yaitu:

a) Tepukan Dribble.

1. Tujuan, tepukan dribble adalah permainan bagus untuk mengembangkan teknik menggiring bola agresif.

2. Pelaksanaan, bagilah suatu suatu bidang bujur sangkar dengan ukuran $7 \mathrm{~m} \times 7 \mathrm{~m}$. Empat siswa masing-masing membawa bola, akan menggiring bola disekitar bidang bujur sangkar ini. Para siswa harus menggunakan punggung kaki untuk menggiring bola. Pada saat menggiring bola, setiap siswa mencoba untuk menepuk siswa lain dan berusaha tidak tertepuk siswa lain dan apabila siswa dapat menepuk punggung siswa yang menggiring bola, maka sebaliknya siswa yang dapat menepuk harus menggiring bola kemudian akan ditepuk punggungnya oleh siswa yang sebaliknya. Bola harus tetap dikuasai oleh siswa. Rangkaian gerakan dapat dilihat pada gambar dibawah ini :

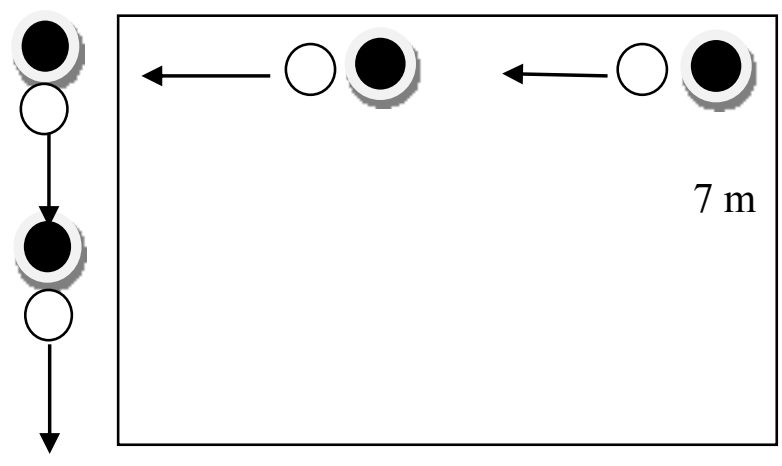

Gambar 2.6. Kegiatan Tepukan Dribble (Mielke 2007:7)

b) Slalom Dribble

1. Tujuan, untuk meningkatkan control serta mempertahankan kecepatan menggiring bola.

2. Pelaksanaan, pasang delapan pancang kerucut secara berderet, jarak antara kerucut yaitu satu meter. Bergeraklah secara zig-zag melewati kedelapan pancang kerucut tersebut kedua arah, kembali ke titik awal. Kemudian, sambil masih sedang menggiring bola, larilah memutari kerucut yang paling jaur dan kembali ke titik awal. Agar permainan ini lebih menarik, tambahkan lagi lebih banyak pemain disetiap percobaan. Rangkaian gerakan ini dapat dilihat pada gambar dibawah ini : 


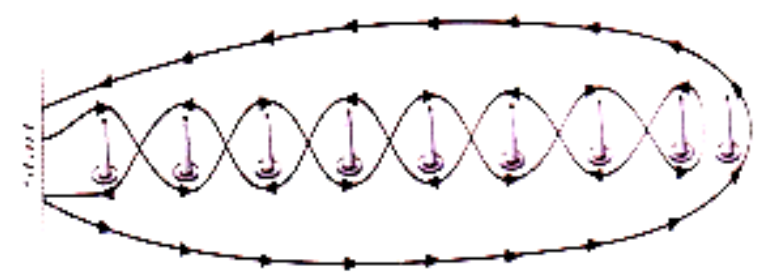

Slatom dribble.

\section{Gambar 2.7. Kegiatan Slalom Dribble (Mielke 2007:8)}

c) Bermain Ekor Keledai

Robert Koger (2007:52) menemukan contoh jenis-jenis variasi latihan untuk dribbling seperti :

1. Persiapan, diperlukan beberapa cones, setiap siswa/pemain harus memiliki bola dan kaus kaki

2. Pelaksanaan, dengan beberapa cones tandailah beberapa batas bidang untuk bermain yang cukup longgar bagi semua siswa/pemain. Semua siswa/pemain harus menyelipkan kaus kaki ke celana meraka, dan ujung kaus kaki itu harus menggantung seperti ekor keledai, dan mereka dilarang menutupi "ekor" tersebut dengan kaus seragam mereka. Perintahkan semua siswa/pemain memasuki area tempat bermain yang sudah anda tandai batasnya dengan cones, lalu tiuplah peluit agar mereka segera bermain. Setiap siswa/pemain harus menggiring bolanya dan terus mengontrol bolanya, sambil mencoba menarik "ekor" siswa/pemain lainnya. Kalau bola mereka sampai lepas kontrol, mereka harus meninggalkan area tempat bermain dan menunggu sampai diperbolehkan ikut bermain kembali. Setiap siswa/pemain yang "ekornya" berhasil ditarik siswa/pemain lain juga menyingkir. Siswa/pemain yang berhasil menarik "ekor" siswa/pemain lain harus membuang "ekor" itu di lapangan. Bisa diperkirakan tinggal berapa pemain saja yang berkejarkejaran di area bermain. Jika jumlah siswa/pemain semakin berkurang, anda juga harus mempersempit bidang area bermain mereka. Kalau siswa/pemain tinggal 2 orang, guru dapat menghentikannya. Karena, kemungkinan besar mereka tidak akan berhenti saling mengejar. Kegiatan bermain ini mengajarkan para siswa/pemain untuk terus mempertahankan bola mereka sekaligus mengontrolnya, dan mewaspadai segala sesuatu yang terjadi di sekitar mereka. Rangkaian gerakan dapat pada gambar dilihat dibawah ini :

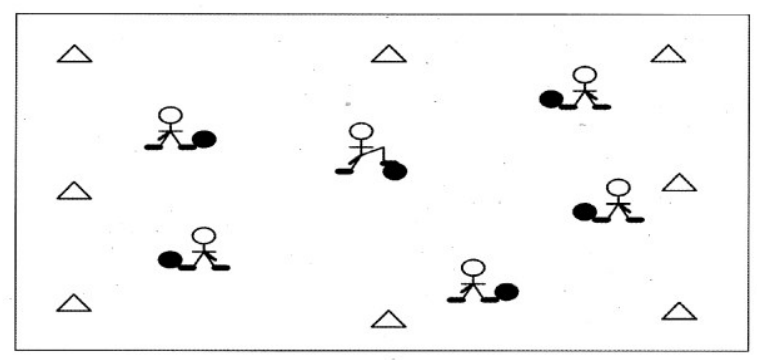




\section{Gambar Kegiatan Bermain Ekor Keledai}

\section{Metode}

Menurut Zainal Aqib (2004:21) "PTK merupakan suatu pencermatan terhadap kegiatan belajar berupa sebuah tindakan yang disengaja dimunculkan di dalam kelas secara bersama". PTK dilaksanakan melalui proses pengkajian berdaur yang terdiri dari empat tahap yaitu: (1) Perencanaan, (2) Tindakan, (3) Observasi, dan (4) Refleksi. Pendekatan yang digunakan adalah pendekatan kualitatif yang berguna untuk mengungkapkan kesulitan belajar siswa dalam proses pembelajaran pendidikan jasmani serta cara mengatasi kesulitankesulitan tersebut sebagai upaya untuk meningkatkan hasil belajar menggiring bola siswa pada materi sepak bola.

\section{Hasil}

Deskripsi Data Penelitian

Berikut ini adalah deskripsi data hasil penelitian yang dimulai dari tes awal, tes siklus I dan tes siklus II. Adapun deskripsi data penelitian yang diperoleh dapat dilihat pada tabel dibawah ini:

Tabel 4.1. Deskripsi Penilaian Proses dan Penilaian Hasil

Menggiring Bola

\begin{tabular}{|c|c|c|c|c|c|c|c|}
\hline \multirow{2}{*}{ No } & \multirow{2}{*}{$\begin{array}{c}\text { Hasil } \\
\text { Belajar }\end{array}$} & \multicolumn{4}{|c|}{$\begin{array}{l}\text { Penilaian Proses } \\
\text { Menggiring Bola }\end{array}$} & \multirow{2}{*}{ Jlh } & \multirow{2}{*}{$\begin{array}{c}\text { Penilaian } \\
\text { Hasil } \\
\text { Menggiring } \\
\text { Bola }\end{array}$} \\
\hline & & & $\begin{array}{l}\text { Sikap } \\
\text { Kaki }\end{array}$ & $\begin{array}{c}\text { Ge rakan } \\
\text { Kepala }\end{array}$ & $\begin{array}{c}\text { Gerakan } \\
\text { Tangan }\end{array}$ & & \\
\hline \multirow{2}{*}{1} & \multirow{2}{*}{ Observasi } & $\sum$ & 58 & 74 & 68 & 200 & 676,32 \\
\hline & & $\dot{\mathbf{X}}$ & 2,15 & 2,74 & 2,52 & 7,41 & 25,05 \\
\hline \multirow{2}{*}{2} & \multirow{2}{*}{ Sirklus I } & $\sum$ & 56 & 91 & 96 & 243 & 644,09 \\
\hline & & $\overline{\mathbf{X}}$ & 2,07 & 3,37 & 3,56 & 9,00 & 23,86 \\
\hline \multirow{2}{*}{3} & \multirow{2}{*}{ Sirklus II } & $\sum$ & 86 & 94 & 92 & 272 & 555,87 \\
\hline & & $\dot{\mathbf{X}}$ & 3,19 & 3,48 & 3,41 & 10,07 & 21,38 \\
\hline
\end{tabular}

Dari tabel diatas dengan jumlah siswa sebanyak 27 diketahui hasil observasi dari penilaian proses menggiring bola dengan tiga indikator yaitu sikap kaki, gerakan kepala dan gerakan tangan dimana setiap indikator mempunyai nilai maksimal 4, untuk indikator pada observasi dimana sikap kaki diperoleh rerata sebesar 2,15, indikator gerakan kepala 2,74, dan indikator gerakan tangan 2,52 jumlah total hasil tes setiap indikator observasi adalah 200 dengan rerata 7,41. Pada kolom penilaian hasil menggiring bola diketahui rata - rata siswa dapat melakukan dribbling mengelilingi cone selama 25,05 detik yang termasuk dalam kategori kurang.

Pada Sirklus I, pembelajaran menggiring bola yang dilaksanakan dengan penerapan variasi mengajar dimana hasil belajarnya belum sesuai dengan yang diharapkan dari 27 
siswa yang mengikuti pembelajaran masih terdapat 17 orang siswa yang belum tuntas hasil belajarnya atau sebesar 58,26\% dan 10 siswa yang sudah tuntas atau sebesar 40,74\%.

\section{Siklus II}

Dari hasil belajar siklus II yang didapat kemudian kembali reduksi dan dipaparkan dalam bentuk tabel dengan menggunakan rumus yang sama seperti siklus I.

Tabel 4.9. Persentase Rata-Rata Tiap Indikator Siklus II

\begin{tabular}{|c|c|c|c|c|}
\hline \multirow{2}{*}{ No } & \multicolumn{3}{|c|}{ Penilaian Proses } & \multirow{2}{*}{$\begin{array}{c}\text { Penialain } \\
\text { Hasil }\end{array}$} \\
\hline & Indikator & Skor & Persentase & \\
\hline 1. & Fase Sikap Kaki & 86 & $79,63 \%$ & \multirow{3}{*}{$\begin{array}{c}\text { Kategori } \\
\text { Baik }\end{array}$} \\
\hline 2. & Fase Gerakan Kepala & 94 & $87,04 \%$ & \\
\hline 3. & Fase Gerakan Tangan & 92 & $85,19 \%$ & \\
\hline
\end{tabular}

\section{Hasil Belajar Siswa Pada Sirklus II}

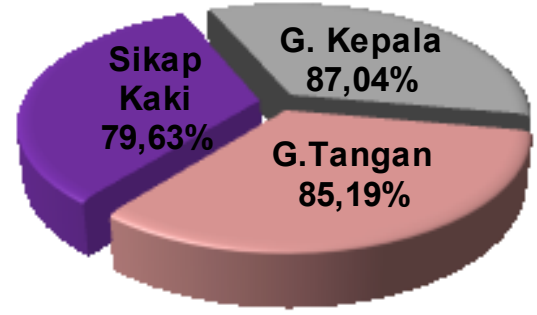

\section{Gambar. Persentase Ketercapaian Indikator Siklus II}

Berdasarkan tabel diatas dapat dilihat sesuai dengan lembar penilaian siswa dari seluruh tahapan-tahapan yang ada dalam pembelajaran penerapan variasi belajar yaitu untuk meningkatkan hasil belajar menggiring bola dimana ketercapaian hasil belajar sirklus II pada fase sikap kaki 79,63\%, fase Gerakan kepala 87,04\% dan fase gerakan tangan 85,19\%.

Adapun kesulitan yang dialami siswa pada siklus I seperti siswa kurang serius dan juga kesulitan yang ditemui dalam melakukan gerakan-gerakan dalam teknik menggiring bola dalam permainan sepak bola sudah dapat diatasi pada sirklus ke dua sehingga hasil belajar pada sirklus II sudah lebih baik dari sirklus I.

Dari perkembagan siklus I dan siklus II dapat dilihat terjadi peningkatan hasil belajar secara individual maupun klasikal telah tercapai. Pada tes hasil belajar I terdapat 40,74\% siswa yang mencapai ketuntasan belajar, pada tes hasil belajar II terdapat 92,59\% siswa yang mencapai ketuntasan belajar dan terjadi peningkatan sebanyak 51,85\% sehingga dapat disimpulkan bahwa pembelajaran menggiring bola melalui penerapan variasi mengajar yang dituangkan pada tes hasil belajar I dan II mengalami peningkatan hasil belajar dan peningkatan ketuntasan belajar baik secara individual maupun klasikal.

\section{Pembahasan}


Dari analisis data yang telah dilakukan dapat disimpulkan melalui penerapan variasi belajar untuk meningkatkan hasil belajar menggiring bola, dari tes hasil belajar sirklus I yang masih rendah yaitu dengan nilai rata-rata sebesar 75,00 dengan ketuntasan 40,74\%. Untuk selanjutnya perlu dilakukannya perbaikan tindakan pada siklus II. Pada siklus I guru menemukan kesulitan yang dialami siswa dalam pembelajaran diantaranya :

1. Masih banyak siswa yang bingung dengan tehnik passing atas yang benar, maka siklus II guru menjelaskan kembali pemahaman tentang tehnik-tehnik menggiring bola.

2. Siswa masih belum maksimal melaksakan tugas dengan tingkatan yang telah diberikan sehingga di siklus II siswa harus dilakukan perbaikan sehingga siswa dapat melakukan tugas dengan baik.

3. Siswa kurang baik melakuan gerakan teknik menggiring bola. Untuk mengatasinya guru mengevaluasi kesalahan siswa dalam melakukan gerakan dan memberikan motivasi kepada siswa.

Pembelajaran menggunakan penerapan variasi belajar pada siklus I ini belum sesuai yang diharapkan dan hasil belajar siswa juga masih rendah. disebabkan siswa masih belum serius melakukan gerakan menggiring bola.

Tabel 4.11. Deskripsi Perbandingan Tes Awal, Hasil Belajar I dan II

Menggiring Bola

\begin{tabular}{|c|c|c|c|}
\hline No & Hasil Tes & Persentase Nilai Rata-rata & Keterangan \\
\hline 1. & Tes Awal & $7,41 \%$ & Tidak Tuntas \\
\hline 2. & Hasil Belajar I & $40,74 \%$ & Tidak Tuntas \\
\hline 3. & Hasil Belajar II & $92,59 \%$ & Tuntas \\
\hline
\end{tabular}

Kemudian pada siklus II dapat dilihat bahwa telah ada peningkatan aktifitas siswa dari siklus sebelumnya. Dari tes hasil analisis yang dilakukan disimpulkan bahwa telah terjadi peningkatan kemampuan siswa. Peningkatan ini terjadi setelah diberikan pembelajaran melalui penerapan variasi belajar yang dirancang pada siklus II yang beracuan pada refleksi dan pengalaman pada siklus I. Pada tes hasil belajar II nilai rata-rata hasil belajar siswa 83,95 dengan tingkat ketuntasan 92,59\% terlihat dari skor yang diperoleh dimana siswa mampu melakukan teknik menggiring bola pada saat tes hasil belajar.

Peningkatan nilai rata-rata hasil belajar siswa yaitu sebesar 8,95 dan peningkatan ketuntasan klasikalnya sebesar 51,85\%, dilihat dari hasil belajar ini maka dapat disimpulkan bahwa penerapan variasi mengajar dapat meningkatkan hasil belajar menggiring bola dalam permainan sepak bola pada siswa kelas VIII SMP Kartika 1 - 2 Medan Tahun Ajaran 2014/2015.

\section{Kesimpulan}

Berdasarkan hasil belajar siswa terdapat peningkatan proses hasil belajar menggiring bola dalam permainan sepak bola dengan penerapan variasi mengajar pada siklus I, setelah tes hasil belajar I dapat dilihat hasil belajar siswa dalam melakukan teknik menggiring bola masih rendah. Dari 27 orang siswa yang menjadi subjek dalam penelitian ini, ternyata hanya 10 orang siswa 
$(40,74 \%)$ yang sudah memiliki ketuntasan belajar, sedangkan selebihnya yaitu 17 orang siswa $(59,26 \%)$ belum memiliki ketuntasan belajar. Nilai rata - rata yang diperoleh hanya mencapai 75,00.

Sedangkan pada siklus II dapat dilihat bahwa kemampuan siswa dalam melakukan tes hasil belajar secara klasikal sudah meningkat. Ternyata dari 27 orang siswa, terdapat 25 orang siswa yang tuntas $(92,59 \%)$ yang sudah memiliki ketuntasan belajar, sedangkan selebihnya yaitu 2 orang siswa $(7,41 \%)$ belum memiliki ketuntasan belajar. Nilai rata - rata yang diperoleh mencapai 83,95.

Berdasarkan hasil peneltian tersebut maka dapat ditarik kesimpulan bahwa hasil belajar menggiring bola dalam permainan sepak bola dapat ditingkatkan dengan penerapan variasi mengajar pada siswa kelas pada siswa kelas VIII SMP Kartika 1 - 2 Medan Tahun Ajaran 2014/2015.

\section{Referensi}

Aqib, Zainal, Penelitian Tindakan Kelas Untuk Guru. Bandung: Yrama Widya, 2006.

Arikunto, Suharsimin, Prosedur Penelitian Suatu Pendekatan Praktik. Jakarta: Rineka Cipta, 2006.

FIFA, Rules Of The Game (Peraturan Permainan). MEDAN: PSSI-UNIMED, 2005.

Hamalik, Oemar, Proses Belajar Mengajar. Jakarta: PT. Bumi Aksara, 2010

Hasibuan, J.J dan Nodjiono, Proses Belajar Mengajar. Bandung: Remaja Rosdakarya, 1986.

Mielke, Danny, Dasar-Dasar Sepak Bola. Jakarta: PT. Pakar Raya, 2007.

Mukholid, Pendidikan Jasmani Olahraga dan Kesehatan. Surakarta,Yudistira, 2007

Nurhasan, Tes Pengukuran Dalam Pendidikan Jasmani. Jakarta. Direktorat Jenderal Olahraga, 2001.

Sarumpaet A, dkk, Permainan Besar. Semarang: Depdikbud, 1992.

Slameto, Belajar dan Faktor - faktor yang Mempengaruhinya. Jakarta: PT. Rineka Cipta, 2010.

Sucipto, dkk, Sepak Bola. Jakarta: Depertemen Pendidikan Nasional Direktorat Jenderal Pendidikan Dasar dan Menengah, 2000.

Sutikno, Sobry, Belajar dan Pembelajaran. Bandung: Prospect, 2007.

Supandi, Strategi Belajar Mengajar Pendidikan Jasmani dan Kesehatan. Jakarta Dekdibud Dirjen Pendidikan Tinggi Proyek Pembinaan Tenaga Kependidikan, 1992. 